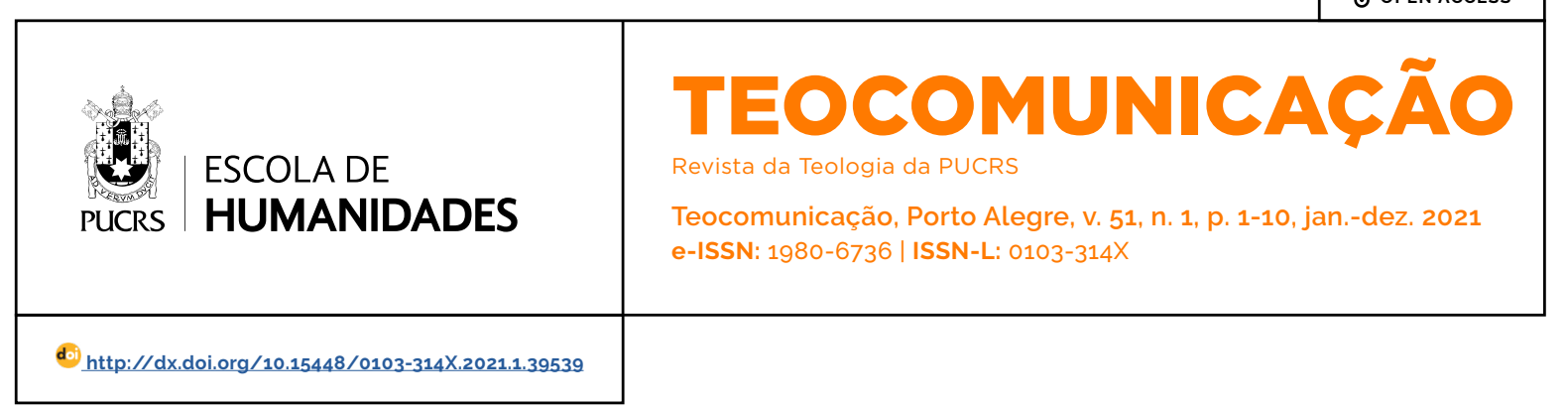

SEÇÃO: LITURGIA

\title{
Descoberta da liturgia como ciência teológica e sua relação com as ciências humanas
}

\author{
Discovery of liturgy as a theological science and its relationship with the human \\ sciences
}

\author{
João José Bezerra ${ }^{1}$ \\ orcid.org/0000-0002-6503-7993 \\ padrejoaojose@hotmail.com
}

Recebido em: 13/11/2020.

Aprovado em: 24/10/2021

Publicado em: 30/12/2021.
Resumo: O presente artigo trata da descoberta da Sagrada Liturgia como ciência teológica e a sua relação com os outros campos das ciências humanas a partir do século XIX. O texto procura apresentar o contexto e as motivações teológicas que impulsionaram os trabalhos de tantos teólogos a reivindicar a posição da liturgia da Igreja, em nivel de igualdade com as demais ciências teológicas, que possuem seu objeto próprio de investigação. Com base nos estudos do teólogo Andréa Grillo, pretende-se recuperar alguns aspectos do percurso dessa "descoberta", apresentando, de forma precisa, seus avanços. Neste artigo, procura-se fazer uma relação da ciência litúrgica com outras ciências: sociologia e antropologia apresentando a relevância e a articulação delas dentro da prática celebrativa, na qual os homens e as mulheres estão envolvidos como sujeitos ativos e participantes. Como fruto desse diálogo, o texto percorre algumas posições do Magistério da Igreja, dentre elas o documento da Conferência Episcopal de Medellín e a Sacrosanctum Concilium, com o intuito de apresentar os esforços e os resultados da Igreja da América-Latina em situar a celebração ritual da Igreja no cotidiano do povo latino-americano.

Palavras-chave: Teologia. Ciências. Liturgia. Rito. Diálogo.

Abstract: The article deals with the discovery of the Sacred Liturgy as a theological science from the 19th century onwards. The text seeks to present the context and theological motivations that drove the work of so many theologians to claim the position of the Church's liturgy on an equal level with other theological sciences that have their own object of investigation. For this, the theologian Andréa Grillo, helps us to go through and recover some aspects of the path of this "discovery", presenting in a precise way the advances of all this work. In a second moment, the text presents the liturgy as a theological science in its relationship with other sciences such as sociology, anthropology, trying to present the relevance and articulation of these within the celebrative practice in which men and women are involved. For this reading, the text uses some positions of the Church's magisterium, such as the document of the Medellin Conference and the Sacrosanctum Council, to present the efforts and results of the Church of Latin America in situating the Church's ritual celebration in the daily life of Latin American people.

Keywords: Theology. Sciences. Liturgy. Rite. Dialogue. 


\section{Introdução}

O presente artigo é fruto de indagações e questionamentos realizados no âmbito das discussões sobre a teologia em diálogo com as outras ciências, fomentadas em sala de aula, do programa de pós-graduação da Pontificia Universidade Católica de São Paulo. Tais discussões lançaram um questionamento fundamental para o campo de pesquisa, que tem como objeto a Sagrada Liturgia. A liturgia enquanto reflexão teológica pode dialogar com as outras ciências? No primeiro e segundo capitulos, iremos percorrer uma parte do caminho histórico da descoberta da liturgia como locus teológico, ou seja, como lugar de reflexão teológica e a sua relação com as ciências humanas. No terceiro capítulo, vamos apresentar a recepção da liturgia no contexto latino-americano e a sua metodologia dialogal com a própria realidade na qual se celebra os mistérios da fé.

Por fim, recuperando alguns números da constituição litúrgica Sacrosanctum Concilium e do documento da Conferência de Medellín procuramos apresentar os frutos desse diálogo e a recepção ritual proposta pela Igreja, em âmbito latino-americano.

\section{Descoberta da liturgia como "locus teológico"}

Sobre essa questão fundamental, vale a pena remontar ao pensamento do teólogo do campo litúrgico e sacramental, Andrea Grillo, sobre sua abordagem a respeito da sua famosa tese questione litúrgica, que procura estabelecer uma relação entre a reflexão teológica (conteúdo) e a forma ritual e vice-versa (GRILLO, 2001, p. 81):

A liturgia - como dimensão teológica - é uma «invenção» do último século. Com as premissas do século XIX, embora tão importantes, quase tudo acontece nos últimos cem anos. A alegação mais significativa desta novidade consiste em reivindicar - da parte da cele- bração litúrgica - uma original dimensão teológica, ou seja, aquela de ser ato "teológico", como surge na reflexão de Festugière, Guardini, Casel, Vagaggini, Marsili. Este é o novum, que não pode ser compreendido só em termos de «nascimento patrístico» ou de "escrúpulo pastoral". Nesse vem dito qualquer coisa de original e inédito, que modifica a compreensão mesma da relação com Cristo (GRILLO, 2011, p. 79, tradução nossa). ${ }^{2}$

Seguindo seu pensamento, o novum dessa descoberta está no fato de que a celebração litúrgica possui um conteúdo a ser considerado pela reflexão teológica. Em outro momento, Grillo irá dizer que a teologia litúrgica já é, enquanto tal, uma disciplina nova, um sinal diferente de uma nova compreensão da relação com Cristo e com a Igreja, através da qual a celebração ritual passa a ser colocada em um novo âmbito significativo, não só a partir do ato de fé em Cristo, mas do próprio Senhor que se revela (GRILLO, 2011, p. 78).

Nessa perspectiva, subentende-se que a celebração litúrgica passa a fazer parte do dinamismo "dialogal" com as outras ciências do âmbito teológico, porque, dentro dessa ritualidade, se encontra o mesmo objeto caro a todas as outras disciplinas teológicas, ou seja, o próprio mistério de Cristo. Por isso, Grillo considera como novum a redescoberta da ação ritual como locus teológico, porque no seio do seu dinamismo ritual encontra-se o autor da nossa fé, Jesus Cristo (GRILLO, 2011, p. 79).

Pode-se dizer que a função da teologia litúrgica, enquanto disciplina nova, é pensar a relação conteúdo-ritualidade e, consequente, conteúdo-ritualidade com o ato de fé do crente. O trunfo dos pioneiros do movimento litúrgico - Festugière, Guardini, Vagaggini, Marsili - foi recuperar a centralidade do mistério de Cristo como objeto da ação ritual. Essa recuperação favorece a percepção da liturgia da Igreja, não como uma realidade fechada em si mesma, mas dinâmica, já que seu objeto é dinâmico por

\footnotetext{
2 Do original: La «liturgia» - come dimensione teologica - è uma «invenzione» dell' ultimo secolo. Con le premesse ottocentesche, pur cosi importanti, quasi tutto avviene negli ultimi cent'anni. La «pretesa» più significativa di questa novità consiste nel revindicare - da parte della celebrazione liturgica - una originale dimensione teologica, ossia quella di essere «atto teologico», come emerge dele riflessioni di Festugière, Guardini, Casel, Vagaggini, Marsili. Questo è il novum, che non può essere compiutamente compreso solo in termini di «rinascita patristica» o di «scrupolo pastorale». In esso viene detto qualcosa di cosi originale e inedito, che modifica la comprensione stessa del raporto con Cristo.
} 
si mesmo. Quando falamos do dinamismo do objeto, queremos afirmar que se trata mais do que um conteúdo pensado e refletido, mas de uma pessoa em relação. A função da teologia litúrgica, antes de tudo, não é refletir sobre a pessoa, mas refletir como se dá a relação do fiel com o Senhor através do dinamismo ritual (GRILLO, 2011, p. 78). Contudo, a liturgia, não é só um problema de ritualidade, mas de conteúdo, de teologia. "Faz parte do DNA do movimento litúrgico ocupar-se da relação com o 'resto' da teologia e com o seu fundamento" (GRILLO, 2011, p. 77-78, tradução nossa). ${ }^{3}$

A marca registrada do movimento litúrgico é colocar outras áreas da teologia como a cristologia, por exemplo, em relação com o fundamento da liturgia. Podemos, contudo, dizer que, o processo da descoberta da teologia como locus liturgicus, implica, ao mesmo tempo, na descoberta da ação ritual como ponte de comunicação entre as outras áreas da teologia e, por consequência, o lugar da própria liturgia no campo teológico: "Existe uma prioridade da liturgia em respeito da cristologia (não é a cristologia que funda a liturgia, mas vice e versa: um Jesus não celebrado não poderia ser pensado como Cristo" (GRILLO, 2011 , p. 85 , tradução nossa). ${ }^{4}$

Neste primeiro momento, pode-se perceber que a teologia litúrgica, fruto do Movimento Litúrgico, tendo como objeto de reflexão o mesmo objeto das outras áreas da teologia, pode estabelecer uma via de diálogo sem desconsiderar a sua particularidade própria, que é a celebração dos mistérios da fé. Por outro lado, a questione liturgica assume para si a dimensão ritual como locus de diálogo entre a teologia litúrgica e as outras áreas da teologia. Resta-nos saber se: o alcance desse diálogo pode suplantar as paredes do próprio campo teológico? A teologia, enquanto ciência, que tem como fundamento o Mistério Pascal, pode dialogar com outras ciências fora do seu próprio campo? Assim como a ritualidade é ponto de diálogo entre as outras áreas da teologia, essa mesma ritualidade pode ser ponte de diálogo entre as outras ciências?

\section{Teologia litúrgica e diálogo com as outras ciências}

\begin{abstract}
Não podemos escutar o Concilio, hoje, se não prestarmos atenção à nossa realidade sociorreligiosa, da mesma forma que o Concílio não pôde colocar-se a escuta do seu contexto sem prestar atenção nas vozes que pediam tanto as reformas quanto o diálogo com o mundo, diálogo que o Concílio autorizou e inaugurou com seu próprio exemplo. A "polifonia" não é exatamente o mesmo que "dialogismo", mas certamente a sua marca. Onde há polifonia pode surgir o dialogismo. Assim a marca dialógica do espírito do Concilio deverá coincidir com a presença da polifonia em sua letra (CARDITA, 2018, p. 55).
\end{abstract}

Cardita, particularmente, trata a questão da liturgia e dialogismo no Vaticano II, mais propriamente, no que diz respeito a participação ativa dos fiéis na liturgia (SC, 14), coloca em evidência outras faces desse diálogo. Qualquer diálogo supõe sempre um sujeito e uma situação real ou social. Essas caracterizações dão credibilidade para que esse diálogo seja real e verdadeiro. Assim, como vimos anteriormente, o locus próprio da teologia litúrgica é a própria ritualidade da Igreja e seus desdobramentos na história. É a partir desse ponto concreto e do seu objeto que a teologia se torna uma realidade dialogal com as outras áreas da teologia. Todo diálogo tem como elementos constitutivos um objeto formal e um contexto real.

O Concilio Vaticano II tem como opção o método dialógico com o mundo e não o fechamento. Esse método implica a Igreja como um todo, sua constituição hierárquica e toda a sua reflexão teológica. Assim como todas as outras áreas da Igreja devem encontrar seus pontos dialogais, não só ad intra, mas, também, ad extra, necessariamente, a liturgia não fica de fora desse método.

À luz do pensamento de Cardita, a metodologia dialógica deve levar em consideração o contexto

\footnotetext{
3 Do original: Fa invece parte del DNA del Movimento Liturgico occuparsi del rapporto con il «resto» della teologia e com il suo fundamento.

4 Do original: «C'è una priorità della liturgia rispetto alla cristologia (non è la cristologia a fondare la liturgia, ma viceversa: un Gesù non celebrato non può potrebbe essere pensato come Cristo».
} 
sociorreligioso para que a recepção dos valores seja possivel, para que o movimento conciliar produzam seus efeitos requeridos.

Brighenti vai afirmar:

O Vaticano II, superando o eclesiocentrismo, bem como o dualismo entre sagrado e profano, temporal e espiritual, corpo e espirito, afirma que a Igreja, ainda sem ser deste mundo, está no mundo e existe para ser mediação de salvação do mundo (LG 50; GS 40). Para isso, precisa encarnar-se nele, assumi-lo, para transfigurá-lo e redimi-lo. (BRIGHENTI, 2017, p. 325).

A sociologia, por sua vez, pode contribuir para uma compreensão da experiência no âmbito ritual, já que esta ciência é, também, um dado antropológico. Por sua vez, ela nos leva a compreender a ação ritual na perspectiva social. O rito não só faz parte de um grupo seleto, especifico, mas diz algo das relações sociais estabelecidas. Do ponto de vista da reflexão teológica, o Concilio procura responder aos anseios do mundo e dos homens, a partir de uma realidade formal, ou seja, o tecido social ou a realidade concreta na qual os homens e as mulheres estão inseridos. Esse é o ponto de partida do método dialogal do Concilio Ecumênico do Vaticano II e trascurar esse princípio seria o mesmo que teologicamente trair os princípios do próprio concilio. Papa Paulo VI, em seu discurso de abertura, vai dizer: ".... na consciência do Magistério eclesiástico a convicção de que a doutrina católica não deve ser somente verdade a ser explorada pela razão sob a luz da fé, mas sim palavra geradora de vida e de ação [...]" (COMPÊNDIO DO VATICANO II, 1968, p. 9.)

A teologia, agora, tem como campo fecundo de investigação teológica não mais somente o campo abstrato das disputas teológica, ela pode contar, também, com a sociologia como ciência, que tem como objeto de investigação as relações do tecido social e suas mutações.

A sociologia pode encontrar na experiência ritual humana respostas para as suas próprias indagações, tais como as questões de socialização, que constroem a identidade sadia dos individuos e das causas da deterioração do tecido social.
Outro compromisso da sociologia é indagar-se sobre os conflitos, tais como: a violência social, a proliferação dos usos de entorpecentes, da exclusão social, do problema relevante da mobilidade dos refugiados de guerra ou motivados por outros fatores sócios-econômicos, bem como a própria disputa pelos bens naturais, que levam a degradação ambiental e, consequentemente, a escassez de alimentos e água e das disputas étnicas religiosas.

Do ponto de vista de uma reflexão sociológica, a experiência ritual poderia oferecer algo de positivo para a compreensão das causas dessa degradação social ou mesmo para a compreensão da construção da identidade do indivíduo e de um grupo social? A deterioração ritual seria uma das causas da degradação social e individual?

A experiência ritual poderia ser um fator relevante para a recuperação da identidade do individuo e do seu contexto social. Parece que, seguindo a esteira do método teológico proposto por Cardita, sobre a consideração de nossa realidade sociorreligiosa (CARDITA, 2018, p. 55), a teologia litúrgica oferece para a sociologia um campo fecundo no âmbito ritual celebrativo, para que a sociologia procure respostas às suas indagações. Por assim dizer, o ponto de encontro entre as duas ciências é a realidade humana repleta de alegrias, tristezas, angústias e esperanças dos homens e das mulheres de hoje. Vai afirmar a Constituição Pastoral:

\begin{abstract}
As alegrias e as esperanças, as tristezas e as angústias dos homens de hoje, sobretudo dos pobres e de todos aqueles que sofrem, são também as alegrias e as esperanças, as tristezas e as angústias dos discipulos de Cristo; e não há realidade alguma verdadeiramente humana que não encontre eco no seu coração. Porque a sua comunidade é formada por homens, que, reunidos em Cristo, são guiados pelo Espírito Santo na sua peregrinação em demanda do reino do Pai, e receberam a mensagem da salvação para a comunicar a todos. Por este motivo, a Igreja sente-se real e intimamente ligada ao gênero humano e à sua história (GS, n. 1).
\end{abstract}

Bem intuiu o Concilio, nesse sentido, de que não existe nenhuma realidade humana que não 
encontre eco no seu coração. Por isso, podemos dizer que a teologia litúrgica, seguindo as aspirações do Movimento Litúrgico e do próprio Concilio Vaticano II, deve considerar a realidade que encontra eco no coração humano.

Uma reflexão teológica que não considera a realidade humana como chave hermenêutica de interpretação da ação de Deus na sua relação divina com seu povo torna-se limitada e nem sempre consegue responder aos anseios e às necessidades dos seres humanos. A teologia deve ser um contributo para a sociedade hoje e para os homens de hoje e não um retrocesso. Vai afirmar o Papa Francisco em sua encíclica sobre o cuidado global e a responsabilidade mútua: "Infelizmente, verifica-se uma indiferença geral perante estas tragédias, que estão acontecendo agora mesmo em diferentes partes do mundo" (Laudato si, n. 25). Para o Vaticano II, "a doutrina não é um conjunto de verdades abstratas, é uma doutrina de vida, da vida divina do Verbo feito carne que deve animar a vida de todos os homens" (COMPÊNDIO VATICANO II, 1968, p. 11).

Considerando o Concilio de que a doutrina deve animar a vida dos homens, que não é em si uma realidade abstrata, mas real, permeada de dores, alegrias, sofrimentos e esperanças, a análise sociológica vem ao encontro não só da teologia fundamental, mas, também, da teologia litúrgica como terreno fértil, possibilitando uma compreensão da própria realidade na qual a experiência ritual se encontra. Papa Francisco em sua exortação apostólica Evangelii Gaudium vai dizer:

Mais do que o temor de falhar, espero que nos mova o medo de nos encerrarmos nas estruturas que nos dão uma falsa proteção, nas normas que nos transformam em juizes implacáveis, nos hábitos em que nos sentimos tranquilos, enquanto lá fora há uma multidão faminta e Jesus repete-nos sem cessar: «Dai-lhes vós mesmos de comer» (MC 6 , 37) (EG, n. 49).

Assim como a reflexão teológica, a liturgia como discurso teológico só terá relevância caso considere a relação do seu objeto (Mistério de Cristo) com a própria realidade (GRILLO, 2011, p. 78). Podemos afirmar, no entanto, que a teologia litúrgica que tem como objeto o Mistério de Cristo procura estabelecer uma relação com seus destinatários: o homem e a mulher de fé situados em suas próprias realidades, no contexto social, marcados pelos dramas das suas histórias que procuram corresponder a esse convite de relação, através de uma determinada experiência ritual.

A relevância da sociologia é oferecer para a teologia litúrgica um espelho do drama social no qual está inserida, para que essa possa corresponder aos seus anseios, através de uma experiência ritual que considere a própria realidade de cada ser humano.

Quando o concilio trata sobre a reforma do rito, em poucas palavras vai dizer: "O rito deve ser caracterizado por uma nobre simplicidade, ser claro e breve, evitar repetições, estar sempre ao alcance dos fiéis e não necessitarem de muitas explicações" (SC, 34). Em outras palavras, a experiência ritual não deve ser um obstáculo para a relação com o transcendente (Deus), mas deve ser uma via de acesso fácil. Porém, tonar-se-á uma via de acesso se os sujeitos da celebração considerarem o rito como parte da realidade. A experiência celebrativa ritual deve se considerar como parte integrante da realidade, deve conter em seu seio o drama da história de cada homem e de cada mulher e, nesse sentido, a sociologia pode oferecer um grande contributo, não somente para uma integralidade da liturgia e da vida.

Assim como a ciência social possui uma grande relevância para a reflexão da teologia litúrgica, as ciências antropológicas surgem, também, como um campo fértil de possibilidades para uma maior compreensão do homem, não somente na sua constituição específica humana, mas, também, da sua dimensão imanente transcendental e sacramental.

Por outro lado, a partir do início do século XIX, em modo mais forte, desde as primeiras décadas do século $X X$, nasceram uma série de novas competências científicas - antes não só desconhecidas, mas impensáveis - que traziam à luz uma série de dimensões escondidas nos sacramentos. Pensamos no trabalho de pesquisa que a antropologia, a psicologia, a sociologia, a etnologia têm conseguido desenvolver e inau- 
gurar sobre os ritos, os mitos, as orações, os sacrificios, a hierarquia, os dons, a comunidade, os elementos simbólicos elementares (GRILLO, 2011, p. 132-133, tradução nossa). ${ }^{5}$

A partir do século XIX e XX, não se sustenta mais uma teologia pensada como território exclusivo, como itha isolada do mundo. Parece que a teologia litúrgica também não só compreendeu os princípios fundamentais do movimento conciliar, mas resolveu acolhê-los plenamente em seu seio. Grillo afirma que nos dois séculos que se passaram, germinou, ao lado da teologia clássica, uma disciplina antropológica, e de outro, uma disciplina litúrgica. Para o autor, a caracteristica fundamental do século XIX e XX é a afirmação de uma disciplina como a antropologia com suas diversas articulações e métodos e, por outro lado, o surgimento da uma nova disciplina como a ciência litúrgica (GRILLO, 2011, p. 132).

Assim como a sociologia oferece para a teologia uma nova compreensão da realidade concreta na qual se estabelece uma determinada experiência ritual de relação com o transcendente (Deus), da mesma forma, a antropologia como ciência oferece um horizonte de possibilidades de compreensão sobre o próprio homem, sua identidade, sua constituição psicológica, cultural e transcendental. Se a sociologia tem como ponto de convergência a realidade social como locus concreto da experiência ritual/transcendental, por sua vez, a antropologia tem como ponto de convergência o homem.

Grillo apresenta a ideia de que a antropologia favorece a recuperação do senso antropológico que nos leva a redescobrir a dimensão imanente, ou seja, a antropologia supera o próprio homem que deve ser compreendido na sua profundidade. A antropologia recupera o homem todo, não só uma parte desse homem. Esse homem possui algo de transcendente que é inerente ao mesmo. O homem não é só realidade transcendente, mas também um sujeito no tempo e no espaço, constituido por dimensões fisicas, psíquicas, anseios, alegrias e angústias. Esse homem é sujeito e destinatário da experiência ritual. Por isso, é preciso, o quanto antes ou constantemente, recuperar uma nova sintese entre teologia e antropologia, o que vai possibilitar pensar a experiência visivel e invisivel da graça que se dá no homem, restaurando o direito da visibilidade, da materialidade e da sensibilidade dos sacramentos (GRILLO, 2011, p. 134).

A necessidade de um diálogo constante da reflexão teológica é de fundamental importância já que a teologia pós-conciliar não só considera a reflexão teológica da Graça como se dava na teologia clássica, do período escolástico, passando por Trento até o Vaticano II. Com a reviravolta teológica e antropológica, deve-se levar em consideração não só a graça, mas também o destinatário da graça. No campo litúrgico, o efeito é o mesmo, não só o rito e a graça, mas a experiência sensivel que o homem faz da graça, através da dinâmica ritual (GRILLO, 2011, p. 136).

\section{Recepção da liturgia reformada como "dialogismo" no contexto latino-americano}

\begin{abstract}
A inculturação litúrgica, visa do lado da liturgia (o lado da cultura merece um estudo a parte), pode ser definida como processo de inserir os textos e o rito da liturgia no marco cultural local. Como resultado disso, os textos e ritos assimilam o padrão de pensamento, linguagem, valor, ritual, simbólico e artístico do povo (CHUPUNGO, 2008, p. 28).
\end{abstract}

A intuição teológica de Chupungo nos reinsere dentro das aspirações do Vaticano II, por isso, à luz do seu pensamento podemos contemplar uma liturgia com profundas marcas sociológicas e antropológicas. Uma expressão ritual que é incapaz de assimilar determinados padrões culturais de pensamento, linguagem, valor ritual e simbólico torna-se uma realidade incomunicável, fechada em si mesma, em último caso, estabelece uma comunicação ad intra, o que não parece ser a proposta conciliar e nem o seu método teológico como vimos. 
A Constituição Dogmática Dei Verbum elucida essa realidade.

\begin{abstract}
Depois de ter falado muitas vezes e de muitos modos pelos profetas, falou-nos Deus nestes nossos dias, que são os últimos, através de Seu Filho (Heb. 1, 1-2). Com efeito, enviou o Seu Filho, isto é, o Verbo eterno, que ilumina todos os homens, para habitar entre os homens e manifestar-lhes a vida intima de Deus (cf. Jo $1,1-18)(D V, 4)$
\end{abstract}

Neste número quatro da Constituição Dogmática, a teologia litúrgica encontra o fundamento da inculturação litúrgica como dialogismo entre Deus e os homens. Jesus, Verbo Divino do Pai, continua a obra do Pai ao entrar na história humana. Esse é o modo que Deus escolheu para dialogar com o homem, para oferecer a sua vida divina e, consequente, a sua graça. O Verbo enviado pelo Pai é o fundamento máximo de toda ação litúrgica da Igreja já que é Ele mesmo que age nas ações litúrgicas (SC, 7). Por sua vez, a liturgia, sendo ação desse Cristo, não pode transgredir a sua natureza de ser um mistério que considere o marco da história coletiva e individual de cada homem. Torna-se cada vez mais urgente descobrir na vida da lgreja essas duas realidades fundamentais, ou seja, que a ação Sagrada da Igreja não está fora e nem alienada da realidade e da história individual de cada homem e de cada mulher

Quando Andrea Grillo fala sobre (rapporto) a relação com Cristo, (GRILLO, 2011, p. 79), ele quer dizer que é próprio da função da natureza da liturgia estabelecer uma relação dialogal entre Deus, que oferece a sua graça no contexto da macro e micro história, ansioso por uma resposta desse mesmo homem. Essa relação se dá plenamente por meio de sinais visiveis que acontecem plenamente na liturgia (SC, 7).

A reforma conciliar, pautada em uma teologia litúrgica sustentada pelas novas ciências, parece expressar claramente uma liturgia que considera o homem-ritus-preces e a realidade na qual esse mesmo homem está inserido. Vejamos:

a) mantendo-se substancialmente a unidade do rito romano, dê-se possibilidade às legitimas diversidades e adaptações aos vários grupos étnicos, regiões e povos, sobretudo nas Missões, de se afirmarem, até na revisão dos livros litúrgicos; tenha-se isto oportunamente diante dos olhos ao estruturar os ritos e ao preparar as rubricas (SC, 38);

b) será da atribuição da competente autoridade eclesiástica territorial, de que fala o art. 22 § 2, determinar as várias adaptações a fazer, especialmente no que se refere à administração dos sacramentos, aos sacramentais, às procissões, à língua litúrgica, à música sacra e às artes, dentro dos limites estabelecidos nas edições típicas dos livros litúrgicos e sempre segundo as normas fundamentais desta Constituição (SC, 39);

c) a competente autoridade eclesiástica territorial, a que se refere o art. $22 \S 2$. desta Constituição, prepare o mais depressa possivel, com base na nova edição do Ritual romano, os Rituais particulares, adaptados às necessidades de cada uma das regiões, mesmo quanto à língua. Procure-se que sejam postos em vigor nas respectivas regiões depois de aprovados pela Sé Apostólica (SC, 63).

Os números acima expressam toda a sensibilidade teológica do Concílio em querer cada vez aproximar o rito litúrgico das realidades humanas e suas aspirações para que esse mesmo rito seja compreensivel, claro, breve e possa alcançar os fiéis na busca de um diálogo.

Uma teologia litúrgica que considere com seriedade esses elementos será certamente, bem como seu próprio rito, uma realidade comunicável. Uma teologia litúrgica que não venha a considerar esses elementos, não favorecerá para que a Sagrada Liturgia seja, de fato, o que ela deve ser: comunicação/relação de Deus com o homem por meio dos sinais sensiveis, através dos quais oferece sua graça (GRILLO, 2011, p. 132).

Podemos afirmar que o surgimento das novas ciências do século XIX e XX como a sociologia, antropologia, não só favoreceram a uma nova compreensão do homem e da sua realidade, mas, também contribuem para um maior entendimento de como esse mesmo homem se relaciona com Deus (GRILLO, 2011, p. 89). 


\section{Recepção ritual latino-americana}

A partir deste ponto, procuraremos demonstrar os aspectos concretos de como a relação entre a liturgia e as outras ciências favoreceram uma maior recepção dos princípios "dialógicos" gestado no seio do Concilio Vaticano II e que, por sua vez, foram acolhidos no seio das conferências latino-americana, de modo particular, a Conferência de Medellín. Promover e implantar uma liturgia que seja expressão do "rosto" do povo latino-americano, acreditamos que tenha sido um dos avanços mais significativos. Trata-se de uma ação litúrgica que é capaz de "dialogar" com o povo e com a própria realidade.

No momento atual da América Latina, como em todos os tempos, a celebração litúrgica comporta e coroa um compromisso com a realidade humana, com o desenvolvimento e com a promoção, precisamente, porque toda a criação está envolvida pelo desígnio salvador que abrange a totalidade do homem (MEDELLíN, 2018, p. 40).

A posição do documento de Medellín acima, deixa transparecer que a teologia da Igreja e todas as suas ações missionárias devem, a partir de agora, considerar um determinado compromisso com a realidade humana, porque sem essa consideração, não só a ação missionária da Igreja bem como sua vida celebrativa tornam-se um sinal inautêntico.

Graças a todo trabalho teológico desenvolvido no âmbito das conferências latino-americanas, a liturgia goza de uma profunda sensibilidade apesar dos presentes sinais de tentativas e retrocessos de impedir que a Sagrada Liturgia seja o rosto de um povo e expressão e marca de uma cultura.

Não faltam tentativas da Igreja da América Latina de dirimir a liturgia da Igreja a um retorno intimista e deslocada da própria realidade, contribuindo para que venha a se tornar uma realidade estranha ao nosso tempo, contrário ao espirito conciliar (SC, 34).

Todo o esforço da teologia litúrgica pós-concilio está em aproximar a liturgia da vida cotidiana dos fiéis e não o contrário, transformando a Sagrada Liturgia em uma propriedade de poucos.
Para facilitar a aplicabilidade dos principios da reforma conciliar como aproximação cultural, o Concilio estabelece os critérios para a formação teológico-ritual:

a) na reforma e incremento da Sagrada Liturgia, deve dar-se a maior atenção a esta plena e ativa participação de todo o povo porque ela é a primeira e necessária fonte onde os fiéis hão de beber o espirito genuinamente cristão. Esta é a razão que deve levar os pastores de almas a procurarem-na com o máximo empenho, através da devida educação (SC, 14);

b) os professores que se destinam a ensinar a sagrada liturgia nos seminários, nas casas de estudos dos religiosos e nas faculdades de teologia, devem receber a formação conveniente em ordem ao seu múnus em institutos para isso especialmente destinados (SC, 15);

c) procurem os pastores de almas fomentar com persistência e zelo a educação litúrgica e a participação ativa dos fiéis, tanto interna como externa, segundo a sua idade, condição, gênero de vida e grau de cultura religiosa, na convicção de que estão cumprindo um dos mais importantes múnus do dispensador fiel dos mistérios de Deus (SC, 19).

Em âmbito latino-americano, destacam-se iniciativas com várias publicações de revistas litúrgicas, como a Revista de Liturgia. Publicações contínuas sobre conteúdo litúrgico das Pias Discípulas, surgiram também, inúmeras publicações das editoras católicas, referentes à natureza da Sagrada Liturgia, bem como sua dimensão celebrativa. Outras contribuições, foram as publicações dos livros litúrgicos e a tradução para a língua vernácula; a inserção da "Oração Eucaristica V", no Missal Romano (1975); as aclamações do povo, inseridas nas orações eucaristicas, para uma maior participação; os inúmeros documentos de estudo da Conferência Nacional dos Bispos do Brasil (CNBB), para organização e para a vida litúrgica no Brasil; as adaptações das celebrações dos rituais do batismo e do matrimônio para a realidade brasileira 
com possibilidades de adaptações pastorais; a possibilidade das celebrações conduzidas por leigos, geralmente nas pequenas comunidades, tanto em âmbito urbano como rural.

Para Frade, tudo isso mostra um grande esforço da Igreja e, porque não dizer, de um vasto trabalho de reflexão teológica (FRADE, 2018 p. 283-284), que tem como fundamento uma sólida contribuição das outras áreas da ciência, destaco aqui, à luz do pensamento de Grillo, a sociologia, psicologia, antropologia, etnologia, para concretizar os ideais dos idealizados pela Constituição Litúrgica Sacrosanctum Concilium.

Ao finalizar este artigo, chama-se a atenção para o salto qualitativo que a teologia deu ao longo dos últimos dois séculos e o quanto vem colaborando para a vida litúrgica da Igreja. Isto levou a refletir sobre a liturgia como fruto de uma sincera abertura às novas ciências.

Pode-se dizer como Grillo que esta invasão de campo das novas ciências (GRILLO, 2011, p. 133) é fruto do Espirito de Deus que atingiu o seu ponto alto na reforma conciliar e que ainda insiste, através dos inúmeros esforços, em implantar as ideias do Concilio e levar a cabo esta obra inacabada.

Como dito, observa-se que o diálogo não é um princípio teórico, mas algo eminentemente prático na vida da pessoa, da Igreja e da sociedade. Está em sintonia com o Vaticano II, ao mostrar que o diálogo é expressão da revelação de Deus com a humanidade no ato revelador (DV2-5) e, por isso mesmo, elemento constitutivo da Igreja (WOLFF, 2018, p. 22).

\section{Considerações finais}

Em caráter de conclusão, podemos dizer que a descoberta da liturgia como nova disciplina teológica deve ser considerada como um marco na história das disciplinas teológicas. Esse marco se trata propriamente de uma grande inversão do ponto de partida da especulação teológica. Se, até então, a teologia clássica pensava as categorias abstratas da fé, com o surgimento da teologia litúrgica, a fé celebrada passou a ser considerada como um dado a ser pensado e redescoberto. Emerge o encontro do Intelectus Fidei com O Intelectus Ritus. A prax-celebrativa passa a ter um papel relevante na reflexão teológica, na medida em que essa se torna fundamento da sistematização teológica. O triunfo desse primeiro momento é a recuperação da intima ligação existente entre o rito e a fé, ou seja, da valorização da prática celebrativa como elemento fundamental para uma profícua vivência da fé.

Outro momento decisivo para a liturgia como ciência teológica é a sua relação com as outras ciências. Fomentada pelos grandes teóricos da liturgia (Guéranger, Festugière, Guardini, Casel, Vagaggini) a teologia não só é capaz de estabelecer uma relação ad intra com as outras ciências teológicas, mas também com as outras ciências humanas (ad extra). Essa relação é possivel tendo em vista que a teologia litúrgica possui um objeto definido provável, que é a própria manifestação do transcendente por meios de sinais sensiveis e invisiveis (ritus) na vida do ser humano situado em uma realidade concreta. A teologia litúrgica não só busca compreender como se dá essa experiência antropológica ritual, mas também tem como função estabelecer princípios teóricos e práticos para que essa experiência seja possivel. De sua parte, as outras ciências com suas descobertas, sejam no campo social, psíquico, etnológico, antropológico, oferecem um campo vasto para que a teologia litúrgica conheça melhor o homem e a mulher que faz a experiência do transcendente.

Por fim, essa discussão leva-nos a perceber que toda reflexão teológica bem fundamentada cientificamente e contextualizada produz frutos significativos na vida da Igreja. Tais frutos são abundantes nos principios traçados pelo Concilio Vaticano II. Reaproximar a liturgia do povo de modo simples e compreensivel, para que essa experiência de Deus não seja abstrata, mas que seja o desdobramento de um Deus que continua atuante na história, pedagogicamente por meio de ritus e preces, ansioso por uma resposta autêntica de fé.

Esses valores também podem ser encontrados em território latino-americano, principalmente, em contexto brasileiro. Os esforços pós Vaticano II constituem-se num grande tesouro e contributo para que a reforma litúrgica atinja o seu 
verdadeiro objetivo que é proporcionar não uma experiência subjetiva e abstrata da fé, mas, sim, uma experiência objetiva da fé.

\section{Referências}

BRIGHENTI, Agenor. Desafios e horizontes de Medellin: para a configuração e organização da Igreja hoje. In: Godoy, Manoel; JUNIOR, Francisco de Aquino. (org.). 50 anos de Medellín: revisitando os textos, retomando o caminho. São Paulo: Paulinas, 2017. p. 306-329.

CARDITA, Ângelo Manuel dos Santos. Reforma litúrgica para quê?: revisando a Sacrossanctum Concilium. São Paulo: Loyola, 2018.

CHUPUNGO, Anscar J. Inculturação litúrgica: sacramentais, religiosidade e catequese. São Paulo: Paulinas, 2008.

CONCÍLIO VATICANO II. Constituição Sacrossanctum Concilium. In: VIER, Frederico (org.). Compendio Vaticano II: constituições, decretos, declarações. 31. ed. Petrópolis: Vozes, 1968. p. 259-306.

CONSELHO EPISCOPAL LATINO-AMERICANO: CELAM. Conclusões das Conferências do Rio de Janeiro, Medellin, Puebla e Santo Domingo. São Paulo: Paulus, 2004.

FRADE, Gabriel dos Santos. Medellin e a liturgia. In: NEY, S; EMERSON, S (org.). Medellin: Memória, profetismo e esperança na América Latina. Petrópolis: Vozes, 2018. p. $274-286$

GRILLO, Andrea. Introduzione alla teologia liturgica: aproccio teórico alla liturgia e ai sacramenti cristiani. Padova: Messagero di Sant' Antonio, 2011.

PAPA Francisco. Evangelii gaudium: esotazione apostólica sull'annuncio del Vangelo nel mondo. 2. ed. Cittá del Vaticano: Librerie Editrice Vaticana, 2013.

POPE Francis. Laudato si. Encyclical letter on care for our common home. Città del Vaticano: Librerie Editrice Vaticana, 2015

SESBOÜÉ, Bernard. História de los dogmas: el hombre y su salvación. Tradução de Afonso Ortiz Garcia. Tomo II. Salamanca: Secretariado Trinitário.

WOLFF, Elias. Igreja em diálogo. São Paulo: Paulinas, 2018.

\section{João José Bezerra}

Mestre em Teologia Dogmática-Sacramentária pelo Pontifício Instituto Litúrgico Sant'Anselmo, em Roma, Itália. Doutorando na área Litúrgica pela Pontificia Universidade Católica de São Paulo (PUC-SP), em São Paulo, SP, Brasil. Padre e professor titular de Teologia Litúrgica e Sacramentos da Iniciação Cristã: Batismo e Confirmação na Faculdade de Teologia João Paulo II (FAJOPA), em Marilia, SP, Brasil.

\section{Endereço para correspondência}

\section{João José Bezerra}

Faculdade de Teologia João Paulo II

Rua Bartolomeu de Gusmão, 531

São Miguel, 17506-280

Marilia, SP, Brasil

Os textos deste artigo foram revisados pela Poá Comunicação e submetidos para validação do autor antes da publicação 